\title{
Biological Nutrition of Tissue Cultured Barhi Date palm off shoots in Comparison with
} Chemical Nutrition

\author{
E. A. Hasaballah; N. A. A. Hagagy ; D. A. Bedeer \\ Horticulture Dept., Faculty of Agric.,Benha University \\ Corresponding author: bentmasr307@yahoo.com
}

\begin{abstract}
Different biological nutrition types i.e. Spirulina platensis algae extract and biostimulant EM1 in comparison with chemical nutrition NPK (Atanor fertile 19). These nutrition types were added with two methods of application i.e. spraying on the leaves at the rate of $20 \mathrm{ml} / \mathrm{L}$ water, $25 \mathrm{ml} / \mathrm{L}$ water, and $4 \mathrm{gm} / \mathrm{L}$ water respectively or injected in the soil with duplicating the concentrations $(40,50 \mathrm{ml} / \mathrm{L}$ water or $8 \mathrm{gm} / \mathrm{L}$ water respectively) of each nutrition type on the Barhi offshoots which derived from two propagation sources (tissue culture \& seed sources) were evaluated either alone or in combinations. It is found that biostimulant EM1 as nutrition type surpassed others in increasing of leaf number, leaf length and shoot thickness parameters of Barhi offshoots. Also, Soil injection of different nutrition types is preferred than spray application in improving leaf number, shoot length, shoot thickness parameters as well as increasing leaf mineral contents \& leaf pigments of Barhi offshoots. Moreover, using different propagation sources (seed or tissue culture derived from Barhi offshoots) had no significant effect on growth parameters and leaf pigments as well as leaf mineral contents. Furthermore, the combined treatment of injection EM1 or Spirulina platensis algae extract in the soil of the seed propagated- offshoots induced improvements in most growth parameters, chloropyll-b, beta carotene $\mathrm{C}$, and total carbohydrates \% as well as some leaf mineral content mainly $\mathrm{N}, \mathrm{K}, \mathrm{Mg}$.
\end{abstract}

Key words: Tissue Cultured, Date palm, Biological, Nutrition, Chemical Nutrition.

\section{Introduction}

Date palm, Phoenix dactylifera L.,Fam. Palmaceae is one of the common and popular fruit grown in tropical and subtropical areas. Date production is about 6.8 million metric tons of fruit (FAO 2007). Over100 million date palm trees are currently grown worldwide on an estimated area of 1 million ha (El-Hadrami and Al-Khayri, 2012). There are many cultivars of date palm, some of them give soft fruits, among which Barhi date palm which is recently introduced to Egypt and is considered the most famous and well distributed in different locations in Egypt.

Date palm traditionally propagated through seed propagation which is not recommended or by offshoots which produce plants identical to their mother trees.To fulfill this huge demand, it is necessary to use the rapid micro-propagation techniques (Tissue culture techniques) which are the only alternative of traditional propagation technique.

The expansion of date palm planting may put a pressure on limited natural resources (land and water) especially it is planted in most cases under harsh and unfavorable growing conditions. Thus adding of nutrition's is urgently needed. Application of NPK liquid fertilizer $(10: 10: 10+$ microelements) at $2 \mathrm{ml} / \mathrm{l}$ as a foliar spray and at 20 $\mathrm{ml} / \mathrm{l}$ as a soil drench to $\mathrm{cv}$. Malacabe palm is greatly recommended to greatly improve trunk length, No. of leaves/plantlet and leaf width as well as increased content of chlorophyll a and b, carotenoids, N, P and $\mathrm{K}$ in the leaves (Abdel-Galeil, 2010). Also, employing of biostimulants that accelerate the biochemical activity within the treated plant and increasing their efficiency in increasing the uptake of necessary nutrients. The use of organic and biostimulants is associated to help low input sustainable agriculture (Russo and Berlyn, 1990). Thus their use decrease the pollution caused by chemicals. The uptake of these nutrients maximize growth and yield of date palms. Effective microorganisms (EM1) is a biostimulant that contains more than 60 selected strains of effective micro-organisms viz.,Photosynthetic bacteria, lactic acid bacteria, yeast, actinomycetes, and various fungi that improve growth and health of plants (Primavesi,1999). Thus, it may be used as foliar treatments or as soil application. The incorporation of factors enabling plants to withstand drought stress would be helpful to improve crop production under drought conditions. Moreover, Mostafa, (2006) stated that EM1 is a biostimulant solution which is defined as effective microorganisms soil improver and it is a mixed culture of beneficial microorganisms (primarily photosynthetic and lactic acid bacteria, yeasts, actinomycetes and fermentation fungi).Also, he added all treatments with yeast or EM1 improved bunch weight, physical and chemical characteristics of date palm fruit cv. Zaghloul dates. Also, Abdel-Galeil,et.al. (2015) recommended application of EM solution at $25 \mathrm{ml} / \mathrm{l}$ and NPK complete fertilizer at $5 \mathrm{~g} / \mathrm{bag}$ to improve growth and quality of 2 year old offshoots of date palm cv. Siwi cultivated in plastic bags before transferring to the permanent field.

Recently, applications of naturals as Spirulina platensis algae extract which are considered as an 
important source of nutrition for sustainable agriculture that are urgently needed. Using Spirulina platensis algae with organic manures in different fruit crops has measurable effect on growth, palm nutritional status, yield and fruit quality (AlySamar, 2015 and Mohamed, 2017). Hussein,(2017) reported that outstanding promotion on yield and fruit quality of Sewy date palms grown under sandy soil was observed due to spraying the palms three times ( $1^{\text {st }}$ week of March, May and July) with a mixture of Spirulina platensis algae at $1 \%$, plant compost tea at $10 \%$, salicylic acid and Tocopherol each at $100 \mathrm{ppm})$. Masoud, (2017) recommended fertilizing the vines with $\mathrm{N}$ (60 g / vine/ year) as $50 \%$ inorganic $\mathrm{N}+50 \%(\mathrm{p} \mathrm{c})$ enriched with $10 \mathrm{ml}(S p$ a) for solving the problem of poor yield of Early sweet grapevines grown under Minia region conditions.

Application method of different nutrition types is greatly important to be fully utilized by plants. In this concern Abdi, and Hedayat, (2010) found that the greater amount of flesh weight, fruit weight, and fruit size of date palm var. 'Kabkabi were resulted from injection method. The mineral nutrients especially iron, increased yield and quality of fruits by injection method of $\mathrm{Fe}$ as it conveys the element directly to the respective parts of plant, using this method could help us to surmount the problem of absorption and transmission of Fe in date palm. Also, propagation source of date offshoots is interested to be evaluated as explained by Al-Ghamdi,(1996 a) who compared between chemical composition of date fruits obtained from four date palm cultivars (Deglet Noor, Medjool, Thoory and Zahdi) propagated through tissue culture and conventional methods. It showed significant differences among cultivars in most of the chemical traits while the chemical properties studied showed a high level of similarity between fruits of plants propagated by tissue culture and those propagated conventionally.

The ultimate goals of this study was to evaluate the effect of different propagation sources of Barhi date palm offshoots (Tissue culture \& seed) and nutrient types (biostimulants nutrition's Spirulina platensis algae extract and EM1 in comparison with chemical nutrition NPK (Atanor fertile 19) alone or in combinations, , with two methods of applications (spray on leaves or injection in soil) to select the best propagation source, type of nutrition and method of application that induced the highest growth parameters of Barhi offshoots.

\section{Materials and Methods}

This experiment was done in Tissue culture Nursery of the Tissue Culture Unit at the Experimental \& Research Station of the Faculty of Agriculture, Benha University. This study was done on acclimatized Barhi date palm offshoots at the same age (3years old) carrying about 4-5 leave and similar in all growth parameters before starting the study. The selected offshoots were resulted either from tissue culture or seed propagation source. These offshoots were planted in large woody containers filled with mixture of sand, peat-moss, and loam at rate $2,1,1$ respectively. This experiment was designed as three factors factorial experiment where nutrition types are the first factor, propagation sources are the second factor and methods of applications were the third factor. ATANOR FERTIL 19)(NPK 19:19:19):a mineral nutrient fertilizer which manufactured by ATANOR EGYPT FOR FERTILIZER MANUFACTORY- ALSALIHYA AL-GEDIDA-EGYPT under license from Atanor products Agricolas, Barcelona, Spain). Also, Spirulina platensis algae extract which is rich in its constituents as tabulated in Table (1) and it is produced as a commercial product by the Central Department of Afforestation, Ministry of Agriculture. Meanwhile, EM1 solution is considered as a biostimulant that contains more than 60 selected strains of "Effective Microorganisms", viz., Photosynthetic bacteria, lactic acid bacteria, yeast, actinomycetes and various fungi that improve growth and health of plants (Primavesi, 1999). EM1 is produced as a commercial Japanese product by the Central Department of Afforestation, Ministry of Agriculture in cooperation with the EM Research Organization, Emro Japan .

Also, Spirulina contains $2.2 \%-3.5 \%$ of RNA and $0.6 \%-1 \%$ of DNA, which represents less than $5 \%$ of these acids, based on dry weight. (Ciferri, 1983; Backer and Venkataraman, 1984, Belay 2002 and 2008; Diraman et. al., 2009; Koru, 2009 and Henrikson, 2010).

The previous mentioned prepared nutrient types i.e. NPK fertilizer (Atanor Fertil 19 NPK 19:19:19, and Spirulina platensis extract or EM1 solution) were applied either as spray on the leaves of offshoots until the solution run-off from their leaves or injected into the soil. The determined quantity of different nutrient types were added into three doses at three times per year at the first of March, mid of April, and first of June.

The study includes the following treatments and formulated as follow:

1-Control: A commercial complete chemical fertilizer NPK ( Atanor Fertil 19 which consisted of 19: 19: 19 NPK sprayed at the rate of $4 \mathrm{~g} / \mathrm{L}$ water on the leaves of offshoots.

2- Injection of NPK at rate $8 \mathrm{~g} / \mathrm{L}$ water in the soil per cage.

3- Spraying of Spirulina platensis algae extract at rate of $20 \mathrm{ml} / \mathrm{L}$ water on leaves of offshoot.

4 -Injection of Spirulina platensis algae extract at rate of $40 \mathrm{ml} / \mathrm{L}$ water in soil per cage.

5- Spraying of EM1 at rate of $25 \mathrm{ml} / \mathrm{L}$ water on leaves of offshoot.

6-Injection of EM1 at rate of $50 \mathrm{ml} / \mathrm{L}$ water in soil per cage. 
7- Spraying of $2 \mathrm{~g} / \mathrm{L}$ water of NPK +Spirulina platensis algae extract at rate of $10 \mathrm{ml} / \mathrm{L}$ water on leaves of offshoot.

8- Injection of $4 \mathrm{~g} / \mathrm{L}$ water of $\mathrm{NPK}+$ Spirulina platensis algae extract at rate $20 \mathrm{ml} / \mathrm{L}$ water in soil .

9- Spraying of $2 \mathrm{~g} / \mathrm{L}$ water of NPK+EM1 at rate of $12.5 \mathrm{ml} / \mathrm{L}$ water on leaves of offshoot.

10- Injection of $4 \mathrm{~g} / \mathrm{L}$ water of NPK+EM1 at rate of $25 \mathrm{ml} / \mathrm{L}$ water in soil per cage. 11-Spraying of Spirulina platensis algae extract at rate $10 \mathrm{ml} / \mathrm{L}$ water + EM1 at rate of $12.5 \mathrm{ml} / \mathrm{L}$ water on leaves of offshoot.

12- Injection of Spirulina platensis algae extract at rate of $20 \mathrm{ml} / \mathrm{L}$ water + EM1 at rate of $25 \mathrm{ml} / \mathrm{L}$ water in soil.

13- Spraying of $1.3 \mathrm{~g} / \mathrm{L}$ water of NPK+ Spirulina platensis algae extract at rate $7 \mathrm{ml} / \mathrm{L}$ water + EM1 at rate of $8.5 \mathrm{ml} / \mathrm{L}$ water on the leaves of offshoot.

14-Injection of $2.6 \mathrm{~g} / \mathrm{L}$ water of $\mathrm{NPK}+$ Spirulina platensis algae extract at rate $13.5 \mathrm{ml} / \mathrm{L}$ water + EM1 at rate of $16.5 \mathrm{ml} / \mathrm{L}$ water in soil per cage.

Table 1. Spirulina platensis analysis as recorded by Barron et al., (2008).

\begin{tabular}{|c|c|}
\hline Parameters & Values Contents (g/100g) \\
\hline Moisture & $3.5 \mathrm{~g}$. \\
\hline Protein & $63.5 \mathrm{~g}$. \\
\hline Fat ( Lipids) & $9.5 \mathrm{~g}$ \\
\hline Fibre & $3.00 \mathrm{~g}$. \\
\hline Ash & $6.70 \mathrm{~g}$. \\
\hline $\mathrm{N}$ - free extract & $15 \mathrm{~g}$. \\
\hline \multicolumn{2}{|l|}{ Pigments } \\
\hline Phycocyanin & $15.6 \mathrm{~g}$. \\
\hline Carotenoids & $456.00 \mathrm{mg}$. \\
\hline Chlorophyll- a & $1.30 \mathrm{~g}$. \\
\hline Vitamins & $(\mathrm{mg})$ \\
\hline Provitamin A & 213 \\
\hline Thiamin & 1.92 \\
\hline \multicolumn{2}{|l|}{$\left(\mathrm{V} . \mathrm{B}_{1}\right)$} \\
\hline Riboflavin (V. $\mathrm{B}_{2}$ ) & 3.44 \\
\hline Vitamin $\mathrm{B}_{6}$ & 0.49 \\
\hline Vitamin $\mathrm{B}_{12}$ & 0.12 \\
\hline Vitamin E & 10.4 \\
\hline Niacin & 11.3 \\
\hline Folic acid & 40 \\
\hline Pantothenic acid & 0.94 \\
\hline Inositol & 76.00 \\
\hline \multicolumn{2}{|l|}{ Minerals } \\
\hline Phosphorus & $916.00 \mathrm{mg}$. \\
\hline Iron & $53.60 \mathrm{mg}$. \\
\hline Calcium & $168 \mathrm{mg}$. \\
\hline Potassium & $1.83 \mathrm{~g}$. \\
\hline Sodium & $1.09 \mathrm{~g}$. \\
\hline Magnesium & $250 \mathrm{mg}$. \\
\hline
\end{tabular}

\section{Data and calculation:}

Data of growth parameters for offshoots \& palms in different treatments in the experiments under study were collected and recorded at the end of each season as well as the measurements and calculations were estimated as follow:

\section{Physical measurements:}

Generally, the following measurements were determined during the two seasons of the study which included the different growth parameters investigated i.e. Leaf number, leaf length $(\mathrm{cm})$, shoot length, shoot thickness $(\mathrm{Cm})$.

Leaf chemical analysis namely leaf pigments chlorophyll a\&b, measured by spectrophotometrically at $660,640 \mathrm{~mm}$ wave-length for chlorophyll (a), (b) \&beta carotenoids respectively, against the blank methanol(termed as $\mathrm{gm} / 100 \mathrm{gm})$, according to method of Saric et al. (1967). Meanwhile, total carbohydrate contents were determined as percentage by using phenol-sulfuric method according to Dubois et al. (1966). Moreover, percentages of $\mathrm{N}, \mathrm{P}, \mathrm{K}$ and $\mathrm{Mg}$ on dry weight basis (Peach and Tracey, 1968; Summer, 1985 and Wilde et al., 1985).

\section{Statistical analysis and experimental design:}

The treatments were arranged in a randomized complete block design (RCBD) and replicated 3 times with one offshoot for each replicate. Data were then tabulated, and subjected to analysis of variance according to SAS Institute Program (1994) and 
used for statistical analysis, whereas Duncan's Multiple Range Test (1955) was employed to verify the differences among the means of different treatments.

\section{Results and discussion}

\section{1-Effect of nutrition types:}

Data in Table (2) clarify that biostimulant EM1 statistically surpassed Spirulina platensis algae extract in increasing leaf number while slightly increased leaf length, shoot length, and shoot thickness without significant differences in the second season. However, EM1 significantly increased leaf length in the second season and shoot thickness in the first season as compared with NPK. However, leaf number, leaf length, shoot length in the first season and both shoot length \& shoot thickness parameters in the second season were failed to show significant differences when either NPK, EM1 or Spirulina platensis algae extract was used.

Table 2. Effect of different nutrition types on growth parameters of Barhi date palm offshoots during both Seasons.

\begin{tabular}{cccccccccccc}
\hline \multirow{2}{*}{ Nutrition type } & \multicolumn{2}{c}{ Leaf number } & \multicolumn{2}{c}{$\begin{array}{c}\text { Leaf length } \\
(\mathbf{C m})\end{array}$} & \multicolumn{2}{c}{$\begin{array}{c}\text { Shoot length } \\
(\mathbf{C m})\end{array}$} & \multicolumn{3}{c}{$\begin{array}{c}\text { Shoot thickness } \\
(\mathbf{C m})\end{array}$} \\
\cline { 2 - 12 } & $\mathbf{2 0 1 7}$ & $\mathbf{2 0 1 8}$ & $\mathbf{2 0 1 7}$ & $\mathbf{2 0 1 8}$ & $\mathbf{2 0 1 7}$ & $\mathbf{2 0 1 8}$ & $\mathbf{2 0 1 7}$ & $\mathbf{2 0 1 8}$ \\
\hline NPK & 5.250 & $\mathrm{~A}$ & $7.7 \mathrm{AB}$ & $81.72 \mathrm{~A}$ & 102.7 & $\mathrm{~B}$ & $5.500 \mathrm{~A}$ & $9.5 \mathrm{~A}$ & 4.075 & $\mathrm{~B}$ & $7.1 \mathrm{~A}$ \\
EM1 & $5.583 \mathrm{~A}$ & $7.9 \mathrm{~A}$ & $88.13 \mathrm{~A}$ & 110.1 & $\mathrm{~A}$ & $5.858 \mathrm{~A}$ & $9.6 \mathrm{~A}$ & 4.583 & $\mathrm{~A}$ & $7.2 \mathrm{~A}$ \\
$\begin{array}{c}\text { Spirulina platensis } \\
\text { algae extract }\end{array}$ & $5.083 \mathrm{~A}$ & 7.0 & $\mathrm{~B}$ & $83.95 \mathrm{~A}$ & $107.4 \mathrm{AB}$ & $5.300 \mathrm{~A}$ & $9.0 \mathrm{~A}$ & 4.225 & $\mathrm{AB}$ & $6.8 \mathrm{~A}$ \\
\hline
\end{tabular}

Means followed by the same letter (s) within each parameter are not statistically different at $1 \%$ level

The aforementioned results showed that the biostemulant EM1 solution stimulated improvements in most of growth parameters through it inducing microorganism's in soil as it contains numerous bioactive contents that greatly stimulated growth parameters. These results are in general agreements with the findings of Primavesi, (1999), who stated that EM1 solution was considered as a biostimulant that contains more than 60 selected strains of "Effective Microorganisms", viz., Photosynthetic bacteria, lactic acid bacteria, yeast, actinomycetes and various fungi that improve growth and health of plants. Also, with the findings of Mostafa, (2006) who indicated that EM1 is a Biostimulant solution which defined as effective micro-organisms soil improver and it is a mixed culture of beneficial microorganisms (primarily photosynthetic and lactic acid bacteria, yeasts, actinomycetes and fermentation fungi). He added all treatments with yeast or EM1 improved bunch weight, physical and chemical characteristics of date palm fruit cv. Zaghloul dates. In addition to findings of Abdel-Galeil, (2010) who assured that biostimulants accelerated the biochemical activity within the treated plant and increasing their efficiency through increasing the uptake of necessary nutrients and improved trunk length, No. of leaves/plantlet and leaf width.

Regarding the effect of application methods, data in Table (3) show that soil injection method significantly maximized the leaf number, shoot length, shoot thickness parameters in the second season as compared with spray application method. However, Slight difference was appeared with leaf length in both seasons and leaf number, shoot length, shoot thickness parameters as soil injection were applied than spray application method. These results concluded that soil injection of different nutrition types surpassed spray application as significantly increase growth parameters of Barhi offshoots. These results are in harmony with the findings of Montasser, et.al. 1993) who found that broadcasting $2 \mathrm{~kg} \mathrm{~K} /$ palm, on the soil surface, either in 2 equal applications in Apr. and Oct. or in 3 equal applications in Feb., Apr. and Oct. induced the best leaf growth, number and length of leaves as compared with the other treatments. Also, with Abdi, and Hedayat, (2010). They found that the greater amount of flesh weight, fruit weight, and fruit size of date palm var. 'Kabkabi were resulted from injection method.

Furthermore, Table (4) reflects the effect of propagation source on growth parameters, it is clear that different propagation sources were failed to induce statistical differences among all parameters under study whereas seed propagation slightly increased leaf number, leaf length, shoot length, and shoot thickness parameters in both seasons in comparison with tissue culture derived.

The before mentioned results summarized that propagation source of date offshoots either through tissue culture or seeds were failed to induce significant differences among different parameters under study. These results are somewhat go in line with findings of Al-Ghamdi,(1996 a) who showed a high level of similarity of chemical properties studied between fruits of plants propagated by tissue culture and those propagated conventionally. 
Table 3. Effect of application methods on growth parameters of Barhi date pam offshoots during both seasons.

\begin{tabular}{|c|c|c|c|c|c|c|c|c|}
\hline \multirow{2}{*}{$\begin{array}{c}\text { application } \\
\text { method }\end{array}$} & \multicolumn{2}{|c|}{ Leaf number } & \multicolumn{2}{|c|}{$\begin{array}{l}\text { Leaf length } \\
(\mathrm{Cm})\end{array}$} & \multicolumn{2}{|c|}{$\begin{array}{l}\text { Shoot length } \\
(\mathrm{Cm})\end{array}$} & \multicolumn{2}{|c|}{$\begin{array}{c}\text { Shoot thickness } \\
(\mathrm{Cm})\end{array}$} \\
\hline & 2017 & 2018 & 2017 & 2018 & 2017 & 2018 & 2017 & 2018 \\
\hline spry & $5.222 \mathrm{~A}$ & $5.8 \mathrm{~B}$ & $83.36 \mathrm{~A}$ & $104.6 \mathrm{~A}$ & $5.461 \mathrm{~A}$ & $8.4 \quad \mathrm{~B}$ & $4.244 \mathrm{~A}$ & $6.3 \mathrm{~B}$ \\
\hline Soil injection & $5.389 \mathrm{~A}$ & $9.2 \mathrm{~A}$ & $85.84 \mathrm{~A}$ & $108.9 \mathrm{~A}$ & $5.644 \mathrm{~A}$ & $10.3 \mathrm{~A}$ & $4.344 \mathrm{~A}$ & $7.8 \mathrm{~A}$ \\
\hline
\end{tabular}

Means followed by the same letter (s) within each parameter are not statistically different at $1 \%$ level

Table 4. Effect of propagation source on growth parameters of Barhi date palm offshoots during both seasons.

\begin{tabular}{cccccccccc}
\hline $\begin{array}{c}\text { propagation } \\
\text { source }\end{array}$ & \multicolumn{2}{c}{ Leaf number } & \multicolumn{2}{c}{$\begin{array}{c}\text { Leaf length } \\
(\mathbf{C m})\end{array}$} & \multicolumn{2}{c}{$\begin{array}{c}\text { Shoot length } \\
(\mathbf{C m})\end{array}$} & \multicolumn{2}{c}{$\begin{array}{c}\text { Shoot thickness } \\
(\mathbf{C m})\end{array}$} \\
\cline { 2 - 12 } & $\mathbf{2 0 1 7}$ & $\mathbf{2 0 1 8}$ & $\mathbf{2 0 1 7}$ & $\mathbf{2 0 1 8}$ & $\mathbf{2 0 1 7}$ & $\mathbf{2 0 1 8}$ & $\mathbf{2 0 1 7}$ & $\mathbf{2 0 1 8}$ \\
\hline $\begin{array}{c}\text { Tissue } \\
\text { culture } \\
\text { seeds }\end{array}$ & $5.278 \mathrm{~A}$ & $7.3 \mathrm{~A}$ & $87.00 \mathrm{~A}$ & $106.1 \mathrm{~A}$ & $5.411 \mathrm{~A}$ & $9.2 \mathrm{~A}$ & $4.322 \mathrm{~A}$ & $7.0 \mathrm{~A}$ \\
\hline
\end{tabular}

Means followed by the same letter (s) within each parameter are not statistically different at $1 \%$ level

Dealing with the interaction between nutrition types and application methods on growth parameters, it is clear from Table (5) that soil injection of NPK solution was significantly superior in increasing leaf number and shoot length than soil injection with spray applications of Spirulina platensis algae extract as well as spray application of either NPK solution or spray of EM1 solution in the second season. However, no statistical difference was discovered in case of leaf number, leaf length, and shoot length in the first season as well as soil injection of NPK solution \& soil injection of EM1 Solution in the second season. However, leaf length was significantly increased as EM1 added as soil injection in comparison with the addition of NPK solution as soil injection. The other treatments showed more or less significant differences in improving leaf length parameter. On the other hand, soil injection of NPK solution, EM1 solution, or Spirulina platensis algae extract showed more or less statistical increase in shoot thickness than spray application of the NPK and Spirulina platensis algae extract.

In general, the results concluded that soil injection of either NPK or EM1 improved most growthparameters of Barhi date palm offshoots. These findings are in accordance with findings of Abdel- Galeil, (2010) who stated that connecting between potassien-N (K-N) at $2 \mathrm{ml} / \mathrm{l}$ as a foliar spray and NPK liquid fertilizer (10: 10: $10+$ microelements) at $20 \mathrm{ml} / \mathrm{l}$ as a soil drench significantly increased trunk length of cv. Sakkoty plant.

Table 5. Effect of interaction between nutrition types and application methods on growth Parameters of Barhi date palm offshoots during both seasons.

\begin{tabular}{|c|c|c|c|c|c|c|c|c|c|}
\hline \multirow{2}{*}{$\begin{array}{c}\text { Nutrition } \\
\text { type }\end{array}$} & \multirow{2}{*}{$\begin{array}{l}\text { Application } \\
\text { method }\end{array}$} & \multicolumn{2}{|c|}{ Leaf number } & \multicolumn{2}{|c|}{$\begin{array}{l}\text { Leaf length } \\
(\mathrm{Cm})\end{array}$} & \multicolumn{2}{|c|}{$\begin{array}{c}\text { Shoot length } \\
(\mathrm{Cm})\end{array}$} & \multicolumn{2}{|c|}{$\begin{array}{c}\text { Shoot thickness } \\
(\mathrm{Cm})\end{array}$} \\
\hline & & 2017 & 2018 & 2017 & 2018 & 2017 & 2018 & 2017 & 2018 \\
\hline \multirow{2}{*}{ NPK } & spry & $5.000 \mathrm{~A}$ & $5.6 \mathrm{C}$ & $80.42 \mathrm{~A}$ & $\begin{array}{l}104.4 \\
\mathrm{ABC}\end{array}$ & $5.200 \mathrm{~A}$ & $8.1 \quad \mathrm{D}$ & $3.983 \mathrm{~B}$ & $6.4 \mathrm{~B}$ \\
\hline & Soil & $5.500 \mathrm{~A}$ & $9.8 \mathrm{~A}$ & $83.03 \mathrm{~A}$ & $100.9 \mathrm{C}$ & $5.800 \mathrm{~A}$ & $10.8 \mathrm{~A}$ & $4.167 \mathrm{AB}$ & $7.9 \mathrm{~A}$ \\
\hline \multirow{2}{*}{ EM1 } & spry & $5.667 \mathrm{~A}$ & $6.3 \mathrm{C}$ & $87.80 \mathrm{~A}$ & $\begin{array}{l}106.7 \\
\mathrm{ABC}\end{array}$ & $5.950 \mathrm{~A}$ & 8.8 CD & $4.683 \mathrm{~A}$ & $6.5 \mathrm{~B}$ \\
\hline & Soil & $5.500 \mathrm{~A}$ & $9.5 \mathrm{AB}$ & $88.45 \mathrm{~A}$ & $113.6 \mathrm{~A}$ & $5.767 \mathrm{~A}$ & $10.3 \mathrm{AB}$ & $4.483 \mathrm{AB}$ & $8.0 \mathrm{~A}$ \\
\hline $\begin{array}{l}\text { Spirulina } \\
\text { platensis }\end{array}$ & spry & $5.000 \mathrm{~A}$ & $5.6 \mathrm{C}$ & $81.85 \mathrm{~A}$ & $102.6 \mathrm{BC}$ & $5.233 \mathrm{~A}$ & $8.2 \quad \mathrm{D}$ & $4.067 \quad \mathrm{~B}$ & $6.1 \mathrm{~B}$ \\
\hline $\begin{array}{c}\text { algae } \\
\text { extract }\end{array}$ & Soil & $5.167 \mathrm{~A}$ & $8.5 \mathrm{~B}$ & $86.05 \mathrm{~A}$ & $112.1 \mathrm{AB}$ & $5.367 \mathrm{~A}$ & $9.8 \mathrm{BC}$ & $4.383 \mathrm{AB}$ & $7.6 \mathrm{~A}$ \\
\hline
\end{tabular}

Means followed by the same letter (s) within each parameter are not statistically different at $1 \%$ level

Considering the effect of interaction between nutrition types and propagation sources, it is appear from Table (6) that propagation source (using either seed or tissue culture derived offshoots) was significantly appeared in leaf number in the second season as interaction between EM1 nutrition type was used in combination with seed propagation in relation to interaction of using of Spirulina platensis algae extract combined with tissue culture derived offshoots. Also, statistical differences were recorded in shoot thickness parameter in the first season as combination of EM1 with either seed or tissue culture compared with NPK with seed propagation. However, the other parameters were showed slight differences without s Data in Table (7) reflect the interaction between application methods and propagation sources of barhi offshoots. It is showed that soil injection of nutrition types in combination 
with seed propagation significantly increased leaf number, leaf length, shoot length, and shoot thickness with view exceptions as compared with spray application of tissue cultured offshoots.

Regarding the interaction between nutrition types, application methods, and propagation sources, Table(8) reveals that adding of either NPK, biostimulant EM1, or Spirulina platensis algae extract nutrition's as soil injection of application method to seed derived barhi offshoots was more or less significantly enhanced leaf number, leaf length, shoot length, and shoot thickness parameters.

Data in Table (9) point out the effect of interaction of nutrition types, application methods, and propagation sources on some leaf pigments of Barhi offshoots. It is quite evident that different treatments used failed to induce significant variances as chlorophyll A parameter considered. However, chlorophyll B was statistically increased as Spirulina platensis algae extract injected in the soil of either seed or tissue culture derived Barhi offshoots in relation to spray or soil injection of NPK to Barhi offshoots with different sources. Similarly, soil injection of EM1 on either seed or tissue culture derived barhi offshoots took the second rank in this respect. Moreover, injection of Spirulina platensis algae extract in the soil significantly maximized beta carotene contents \& total carbohydrates percentages in the leaves of tissue culture derived barhi offshoots as compared with the other interactions.

Table 6. Effect of interaction between nutrition types and propagation sources on growth parameters of Barhi date palm offshoots during both seasons.

\begin{tabular}{|c|c|c|c|c|c|c|c|c|c|}
\hline \multirow[t]{2}{*}{ Nutrition type } & \multirow{2}{*}{$\begin{array}{l}\text { propagation } \\
\text { source }\end{array}$} & \multicolumn{2}{|c|}{ Leaf number } & \multicolumn{2}{|c|}{$\begin{array}{l}\text { Leaf length } \\
(\mathrm{Cm})\end{array}$} & \multicolumn{2}{|c|}{$\begin{array}{c}\text { Shoot length } \\
(\mathrm{Cm})\end{array}$} & \multicolumn{2}{|c|}{$\begin{array}{c}\text { Shoot thickness } \\
(\mathbf{C m})\end{array}$} \\
\hline & & 2017 & 2018 & 2017 & 2018 & 2017 & 2018 & 2017 & 2018 \\
\hline \multirow{2}{*}{ NPK } & tissue & $5.333 \mathrm{~A}$ & $7.6 \mathrm{AB}$ & $82.33 \mathrm{~A}$ & $95.3 \mathrm{~B}$ & $5.333 \mathrm{~A}$ & $9.4 \mathrm{~A}$ & $4.200 \mathrm{AB}$ & $7.2 \mathrm{~A}$ \\
\hline & seed & $5.167 \mathrm{~A}$ & $7.8 \mathrm{AB}$ & $81.12 \mathrm{~A}$ & $109.9 \mathrm{~A}$ & $5.667 \mathrm{~A}$ & $9.6 \mathrm{~A}$ & $3.950 \mathrm{~B}$ & $7.1 \mathrm{~A}$ \\
\hline \multirow{2}{*}{ EM1 } & tissue & $5.500 \mathrm{~A}$ & $7.5 \mathrm{AB}$ & $90.83 \mathrm{~A}$ & $112.7 \mathrm{~A}$ & $5.683 \mathrm{~A}$ & $9.5 \mathrm{~A}$ & $4.567 \mathrm{~A}$ & $7.1 \mathrm{~A}$ \\
\hline & seed & $5.667 \mathrm{~A}$ & $8.3 \mathrm{~A}$ & $85.42 \mathrm{~A}$ & $107.6 \mathrm{~A}$ & $6.033 \mathrm{~A}$ & $9.7 \mathrm{~A}$ & $4.600 \mathrm{~A}$ & $7.4 \mathrm{~A}$ \\
\hline \multirow{2}{*}{$\begin{array}{c}\text { Spirulina } \\
\text { platensis algae } \\
\text { extract }\end{array}$} & tissue & $5.000 \mathrm{~A}$ & $6.8 \mathrm{~B}$ & $87.83 \mathrm{~A}$ & $110.2 \mathrm{~A}$ & $5.217 \mathrm{~A}$ & $8.9 \mathrm{~A}$ & $4.200 \mathrm{AB}$ & $6.8 \mathrm{~A}$ \\
\hline & seed & $5.167 \mathrm{~A}$ & $7.3 \mathrm{AB}$ & $80.07 \mathrm{~A}$ & $\begin{array}{c}104.6 \\
\mathrm{AB}\end{array}$ & $5.383 \mathrm{~A}$ & $9.1 \mathrm{~A}$ & $4.250 \mathrm{AB}$ & $6.8 \mathrm{~A}$ \\
\hline
\end{tabular}

Means followed by the same letter (s) within each parameter are not statistically different at $1 \%$ level

Table 7. Effect of interaction between propagation sources and application methods season on growth parameters of Barhi date palm offshoots during both seasons.

\begin{tabular}{|c|c|c|c|c|c|c|c|c|c|c|c|c|c|c|c|c|}
\hline \multirow{3}{*}{ Interaction } & \multicolumn{4}{|c|}{ Leaf length } & \multicolumn{4}{|c|}{$\begin{array}{l}\text { Leaf length } \\
(\mathrm{Cm})\end{array}$} & \multicolumn{4}{|c|}{$\begin{array}{c}\text { Shoot length } \\
(\mathrm{Cm})\end{array}$} & \multicolumn{4}{|c|}{$\begin{array}{l}\text { Shoot thickness } \\
\text { (Cm) }\end{array}$} \\
\hline & \multicolumn{2}{|c|}{ tissue } & \multicolumn{2}{|c|}{ seed } & \multicolumn{2}{|c|}{ tissue } & \multicolumn{2}{|c|}{ seed } & \multicolumn{2}{|c|}{ tissue } & \multicolumn{2}{|c|}{ seed } & \multicolumn{2}{|c|}{ tissue } & \multicolumn{2}{|c|}{ seed } \\
\hline & 1917 & 1918 & 1917 & 1918 & 1917 & 1918 & 1917 & 1918 & 1917 & 1918 & 1917 & 1918 & 1917 & 1918 & 1917 & 1918 \\
\hline \multirow{2}{*}{ spry } & 5.222 & 5.8 & 5.222 & 5.8 & 87.89 & 106.6 & 78.82 & 102.6 & 5.367 & 8.4 & 5.556 & 8.4 & 4.311 & 6.2 & 4.333 & 6.4 \\
\hline & A & $\mathrm{C}$ & A & $\mathrm{C}$ & A & $\mathrm{AB}$ & B & B & A & B & A & B & A & B & A & B \\
\hline \multirow{2}{*}{ soil } & 5.333 & 8.7 & 5.444 & 9.7 & 86.11 & 105.6 & 85.58 & 112.1 & 5.456 & 10.1 & 5.833 & 10.5 & 4.178 & 7.8 & 4.356 & 7.8 \\
\hline & A & B & A & A & $\mathrm{AB}$ & $\mathrm{AB}$ & $\mathrm{AB}$ & A & A & A & A & A & A & A & A & A \\
\hline
\end{tabular}

Means followed by the same letter (s) within each parameter are not statistically different at $\%$ level

The afore mentioned results summarized that injection of Spirulina platensis algae extract in the soil was effective in increasing of most leaf pigments of barhi offshoots. These results are in agreements with the findings of Hussien, (2017) who found that spraying of Sewy date palms grown in sandy soil with Spirulina platensis algae, plant compost tea, salicylic acid and Tocopherol singly or in combined application was significantly effective in enhancing leaf pigments namely chlorophylls a, b, total chlorophylls, total carotenoids in the leaves relative to the control treatment.

Table 8. Effect of interaction between nutrition types, propagation sources and application methods season on growth parameters of Barhi date palm offshoots during both seasons.

\begin{tabular}{|c|c|c|c|c|c|c|c|c|c|c|c|c|c|c|c|c|c|}
\hline \multirow{3}{*}{$\begin{array}{c}\text { Nutrition } \\
\text { type }\end{array}$} & \multirow{3}{*}{$\begin{array}{l}\text { Application } \\
\text { method }\end{array}$} & \multicolumn{4}{|c|}{ Leaf number } & \multicolumn{4}{|c|}{$\begin{array}{l}\text { Leaf length } \\
(\mathbf{C m})\end{array}$} & \multicolumn{4}{|c|}{$\begin{array}{l}\text { Shoot length } \\
\text { (Cm) }\end{array}$} & \multicolumn{4}{|c|}{$\begin{array}{l}\text { Shoot thickness } \\
(\mathbf{C m})\end{array}$} \\
\hline & & \multicolumn{2}{|c|}{ tissue } & \multicolumn{2}{|c|}{ seed } & \multicolumn{2}{|c|}{ tissue } & \multicolumn{2}{|c|}{ seed } & \multicolumn{2}{|c|}{ tissue } & \multicolumn{2}{|c|}{ seed } & \multicolumn{2}{|c|}{ tissue } & \multicolumn{2}{|c|}{ seed } \\
\hline & & 2017 & 2018 & 2017 & 2018 & 2017 & 2018 & 2017 & 2018 & 2017 & 2018 & 2017 & 2018 & 2017 & 2018 & 2017 & 2018 \\
\hline \multirow{4}{*}{ NPK } & \multirow[b]{2}{*}{ spry } & 5.333 & 6.0 & 4.667 & 5.3 & 85.33 & 104 & 75.50 & 104 & 5.267 & 8.3 & 5.133 & 7.9 & 4.300 & 6.5 & 3.667 & 6.2 \\
\hline & & A & $\mathrm{D}$ & A & D & $\mathrm{ABC}$ & $\mathrm{AB}$ & $\mathrm{BC}$ & $\mathrm{AB}$ & A & $\mathrm{CD}$ & A & D & $\mathrm{ABC}$ & $\mathrm{CDE}$ & C & $\mathrm{DE}$ \\
\hline & \multirow{2}{*}{ Soil app } & 5.333 & 9.3 & 5.667 & 10.3 & 79.33 & 86.73 & 86.73 & 115.0 & 5.400 & 10.4 & 6.200 & 11.3 & 4.100 & 7.8 & 4.233 & 7.9 \\
\hline & & A & $\mathrm{AB}$ & A & A & $\mathrm{ABC}$ & C & $\mathrm{ABC}$ & A & A & $\mathrm{AB}$ & A & A & $\mathrm{BC}$ & $\mathrm{AB}$ & $\mathrm{ABC}$ & $\mathrm{AB}$ \\
\hline \multirow{4}{*}{ EM1 } & \multirow{2}{*}{ spry } & 5.333 & 6.0 & 6.000 & 6.6 & 88.67 & 107.3 & 86.93 & 106.1 & 5.567 & 8.5 & 6.333 & 9.1 & 4.433 & 5.9 & 4.933 & 7.1 \\
\hline & & A & $\mathrm{D}$ & A & $\mathrm{CD}$ & $\mathrm{ABC}$ & $\mathrm{AB}$ & $\mathrm{ABC}$ & $\mathrm{AB}$ & A & $\mathrm{CD}$ & A & BCD & $\mathrm{ABC}$ & E & A & $\mathrm{BCD}$ \\
\hline & \multirow{2}{*}{ Soil app } & 5.667 & 9.0 & 5.333 & 10.0 & 93.00 & 118.0 & 83.90 & 109.1 & 5.800 & 10.4 & 5.733 & 10.3 & 4.700 & 8.2 & 4.267 & 7.8 \\
\hline & & A & $\mathrm{AB}$ & A & A & A & A & $\mathrm{ABC}$ & $\mathrm{AB}$ & A & $\mathrm{AB}$ & A & $\mathrm{AB}$ & $\mathrm{AB}$ & A & $\mathrm{ABC}$ & $\mathrm{AB}$ \\
\hline \multirow{4}{*}{$\begin{array}{c}\text { Spirulina } \\
\text { platensis } \\
\text { algae } \\
\text { extract }\end{array}$} & \multirow{2}{*}{ spry } & 5.000 & 5.6 & 5.000 & 5.6 & 89.67 & 108.3 & 74.03 & 96.83 & 5.267 & 8.2 & 5.200 & 8.2 & 4.200 & 6.3 & 3.933 & 5.9 \\
\hline & & A & D & A & D & $\mathrm{AB}$ & $\mathrm{AB}$ & C & $\mathrm{BC}$ & A & $\mathrm{CD}$ & A & $\mathrm{CD}$ & $\mathrm{ABC}$ & $\mathrm{DE}$ & $\mathrm{BC}$ & E \\
\hline & \multirow{2}{*}{ Soil app } & 5.000 & 8.0 & 5.333 & 9.0 & 86.00 & 112.0 & 86.10 & 112.3 & 5.167 & 9.6 & 5.567 & 10.0 & 4.200 & 7.4 & 4.567 & 7.8 \\
\hline & & A & $\mathrm{BC}$ & A & $\mathrm{AB}$ & $\mathrm{ABC}$ & A & $\mathrm{ABC}$ & A & A & $\mathrm{BC}$ & A & $\mathrm{AB}$ & $\mathrm{ABC}$ & $\mathrm{ABC}$ & $\mathrm{AB}$ & $\mathrm{AB}$ \\
\hline
\end{tabular}

Means followed by the same letter (s) within each parameter are not statistically different at $1 \%$ level 
Table (10) explains the effect of interaction of nutrition types, methods of application, and propagation sources on Barhi offshoots. It is clear that leaf $\mathrm{N}$ content was significantly increased as Spirulina platensis algae extract sprayed on the leaves of seed derived Barhi offshoots in relation to the other combinations. However statistical differences were lacked among different interactions effect on leaf $\mathrm{P} \& \mathrm{Fe}$ contents of Barhi offshoots. On the other hand, soil injection of EM1 was significantly succeeded in increasing of leaf $\mathrm{K}$ content of seed or tissue cultured propagated Barhi offshoots as compared with soil injection of Spirulina platensis algae extract. Furthermore, leaf $\mathrm{Mg}$ content was statistically increased as soil injection of NPK nutrition on either seed or tissue culture resulted Barhi offshoots in comparison with soil injection of either Spirulina platensis algae extract or EM1 nutrition on either seed or tissue culture derived Barhi off shoots.
The before mentioned results indicated that soil injection of Spirulina platensis algae extract increased leaf $\mathrm{N}$ content ,soil injection of EM1 increased leaf $\mathrm{K}$ content and soil injection of NPK maximized leaf $\mathrm{Mg}$ content. These results are somewhat alike with findings of Kasem, et.al. (1997). They found that leaf $\mathrm{N}, \mathrm{Ca}$ and $\mathrm{Mg}$ contents were increased significantly with rates of $\mathrm{N}>4.5$ $\mathrm{kg} /$ tree, while leaf $\mathrm{Fe}$ and $\mathrm{Zn}$ contents were significantly decreased with increasing rate of leaf $\mathrm{N}$. $\mathrm{K}$ application tended to decrease leaf $\mathrm{Ca}$ and $\mathrm{Mg}$ content and increase leaf $\mathrm{N}$ and $\mathrm{K}$ content. Also, with findings of Hussien, (2017) who showed that spraying of Sewy date palms grown in sandy soil with Spirulina platensis algae, plant compost tea, salicylic acid and Tocopherol singly or in combined application was significantly effective in increasing of $\mathrm{N}, \mathrm{P}, \mathrm{K}$ and $\mathrm{Mg}$ in the leaves relative to the control treatment.

Table 9. Effect of interaction between nutrition types, application methods and propagation Sources on some leaf pigments of Barhi date palm offshoots.

\begin{tabular}{|c|c|c|c|c|c|c|c|c|c|c|}
\hline \multirow[t]{2}{*}{ Nutrition type } & \multirow[t]{2}{*}{$\begin{array}{l}\text { Application } \\
\text { method }\end{array}$} & \multicolumn{2}{|c|}{$\begin{array}{c}\text { Chlorophyll } \\
\text { A } \\
\text { gm/100gm }\end{array}$} & \multicolumn{2}{|c|}{$\begin{array}{c}\text { Chlorophyll- } \\
\text { B } \\
\text { gm/100gm }\end{array}$} & \multicolumn{2}{|c|}{$\begin{array}{c}\text { Beta-carotene C } \\
\text { gm/100gm }\end{array}$} & \multicolumn{3}{|c|}{$\begin{array}{c}\text { Total carbohydrates } \\
\%\end{array}$} \\
\hline & & T. c & Seed & T. c & Seed & T. c & Seed & T.c & \multicolumn{2}{|c|}{ Seeds } \\
\hline \multirow{3}{*}{ NPK } & \multirow{2}{*}{ spray } & \multirow{2}{*}{$0.05 \mathrm{~A}$} & \multirow{2}{*}{$0.04 \mathrm{~A}$} & 0.19 & 0.18 & 1.31 & 1.32 & 24.50 & \multirow{2}{*}{\multicolumn{2}{|c|}{$\begin{array}{c}23.50 \\
\mathrm{~L}\end{array}$}} \\
\hline & & & & $\mathrm{D}$ & $\mathrm{D}$ & $\mathrm{D}$ & $\mathrm{D}$ & I & & \\
\hline & Soil app & $0.03 \mathrm{~A}$ & $0.03 \mathrm{~A}$ & $\begin{array}{l}0.21 \\
\mathrm{CD}\end{array}$ & $\begin{array}{c}0.21 \\
\mathrm{CD}\end{array}$ & $\begin{array}{c}1.19 \\
\mathrm{E}\end{array}$ & $\begin{array}{c}1.18 \\
\mathrm{E}\end{array}$ & $\begin{array}{c}28.33 \\
E\end{array}$ & 27.89 & $\mathrm{~F}$ \\
\hline \multirow[t]{2}{*}{ EM1 } & spray & $0.04 \mathrm{~A}$ & $0.03 \mathrm{~A}$ & $\begin{array}{c}0.20 \\
\mathrm{D}\end{array}$ & $\begin{array}{l}0.23 \\
\mathrm{BCD}\end{array}$ & $\begin{array}{c}1.30 \\
\mathrm{D}\end{array}$ & $\begin{array}{c}1.23 \\
\mathrm{E}\end{array}$ & $\begin{array}{c}24.09 \\
\mathrm{~J}\end{array}$ & \multicolumn{2}{|l|}{$\begin{array}{c}23.88 \\
\mathrm{~K}\end{array}$} \\
\hline & Soil app & $0.05 \mathrm{~A}$ & $0.04 \mathrm{~A}$ & $\begin{array}{l}0.27 \\
\mathrm{AB}\end{array}$ & $\begin{array}{l}0.26 \\
\mathrm{ABC}\end{array}$ & $\begin{array}{c}1.47 \\
\mathrm{C}\end{array}$ & $\begin{array}{c}1.44 \\
\mathrm{C}\end{array}$ & $30.33 \mathrm{C}$ & 29.70 & $\mathrm{D}$ \\
\hline \multirow{2}{*}{$\begin{array}{l}\text { Spirulina platensis } \\
\text { algae extract }\end{array}$} & spray & $0.05 \mathrm{~A}$ & $0.04 \mathrm{~A}$ & $\begin{array}{c}0.19 \\
\mathrm{D}\end{array}$ & $\begin{array}{c}0.18 \\
\mathrm{D}\end{array}$ & $\begin{array}{c}1.31 \\
\mathrm{D}\end{array}$ & $\begin{array}{c}1.30 \\
\mathrm{D}\end{array}$ & $\begin{array}{c}26.18 \\
\mathrm{G}\end{array}$ & \multicolumn{2}{|l|}{25.16} \\
\hline & Soil app & $0.08 \mathrm{~A}$ & $0.06 \mathrm{~A}$ & $0.30 \mathrm{~A}$ & $\begin{array}{c}0.28 \\
\mathrm{AB}\end{array}$ & $1.67 \mathrm{~A}$ & $1.56 \mathrm{~B}$ & $31.58 \mathrm{~A}$ & 31.50 & B \\
\hline
\end{tabular}

Table 10. Effect of interaction between nutrition types, application methods and propagation sources on some leaf mineral contents of Barhi offshoots.

\begin{tabular}{|c|c|c|c|c|c|c|c|c|c|c|c|}
\hline \multirow{2}{*}{ Nutrition type } & \multirow{2}{*}{$\begin{array}{l}\text { Application } \\
\text { method }\end{array}$} & \multicolumn{2}{|c|}{ N\% } & \multicolumn{2}{|c|}{ P \% } & \multicolumn{2}{|c|}{ K \% } & \multicolumn{2}{|c|}{$\mathrm{Fe} \%$} & \multicolumn{2}{|c|}{ Mg \% } \\
\hline & & T. c & Seed & T. c & Seed & T. c & Seed & T.c & Seed & T.c & Seed \\
\hline \multirow{4}{*}{ NPK } & \multirow{2}{*}{ spray } & 1.06 & 0.05 & 0.23 & 0.22 & 1.40 & 1.38 & 0.05 & 0.06 & 0.34 & 0.36 \\
\hline & & $\mathrm{BC}$ & $\mathrm{F}$ & A & A & $\mathrm{AB}$ & $\mathrm{AB}$ & A & A & $\mathrm{ABC}$ & $\mathrm{AB}$ \\
\hline & \multirow{2}{*}{ Soil } & 0.68 & 0.56 & 0.19 & 0.17 & 1.42 & 1.40 & 0.08 & 0.08 & 0.42 & 0.41 \\
\hline & & $\mathrm{DE}$ & E & A & A & $\mathrm{AB}$ & $\mathrm{AB}$ & A & A & A & A \\
\hline \multirow{4}{*}{ EM1 } & \multirow{2}{*}{ spray } & 1.05 & 1.06 & 0.21 & 0.22 & 1.38 & 1.37 & 0.05 & 0.06 & 0.35 & 0.36 \\
\hline & & $\mathrm{BC}$ & BC & A & A & $\mathrm{AB}$ & B & A & A & $\mathrm{ABC}$ & $\mathrm{AB}$ \\
\hline & \multirow{2}{*}{ Soil } & 1.02 & 1.02 & 0.14 & 0.15 & 1.53 & 1.53 & 0.05 & 0.05 & 0.22 & 0.20 \\
\hline & & $\mathrm{BC}$ & $\mathrm{BC}$ & A & A & A & A & A & A & BCD & CD \\
\hline \multirow{4}{*}{$\begin{array}{c}\text { Spirulina } \\
\text { platensis algae } \\
\text { extract }\end{array}$} & \multirow{2}{*}{ spray } & 1.08 & 1.32 & 0.20 & 0.20 & 1.39 & 1.39 & 0.06 & 0.05 & 0.36 & 0.35 \\
\hline & & B & A & A & A & $\mathrm{AB}$ & $\mathrm{AB}$ & A & A & $\mathrm{AB}$ & $\mathrm{ABC}$ \\
\hline & \multirow{2}{*}{ Soil } & 0.91 & 0.86 & 0.12 & 0.10 & 1.02 & 1.02 & 0.05 & 0.05 & 0.18 & 0.17 \\
\hline & & $\mathrm{BC}$ & $\mathrm{CD}$ & A & A & $\mathrm{C}$ & $\mathrm{C}$ & A & A & D & D \\
\hline
\end{tabular}

Means followed by the same letter (s) within each parameter are not statistically different at $1 \%$ level

\section{References}

Abdel-Galeil L. M. (2010). Response of date palm plantlets $\mathrm{CV}$. Malacabe to some fertilization treatments. J. Biol. Chem. \& Environ. Sci., 5(1): 43-55.

Abdel-Galeil, L. M.; El-Sayed, B. A.; Shahin, S. M.( 2015). influence of chemical fertilizer, EM 
biostimulant and their combinations on growth and quality of Phoenix dactylifera L. cv. Siwi offshoots. Scientific Journal of Flowers and Ornamental Plants; 2015. 2(1):93-100. 27 ref.

Abdi, G. H.; Hedayat, M.(2010):Yield and fruit physiochemical characteristics of 'Kabkab' date palm as affected by methods of potassium fertilization.Advances in Environmental Biology; 2010. 4(3):437-442. 33 ref.

Ahmed, F. F. and Morsy, M. H. (1999).A new method for measuring leaf area in different fruit species. Minia. J. of Agric.Rec. \& Dev.19: 97 105.

Al-Ghamdi, A. S.(1996 a): Field evaluation of date palm (Phoenix dactylifera L.) cultivars produced through tissue culture techniques. 4. Fruit chemical properties. Bulletin of Faculty of Agriculture, University of Cairo; 1996. 47(1):167-177. 26 ref.

Aly-Samar, S.H. (2015): Influence of reducing mineral nitrogen fertilizer partially by using plant compost enriched with spirulinaplatensis algae fruiting of Flame seedless grapevines. M.Sc., Thesis. Fac. of Agric. Minia Univ. Backer,E.W. and Venkataraman, L.V.(1984).Production and utilization of the blue- green algae Spirulina in India, Biomass, Volume 4, Issue 2, pp. 105-125.

Barron, L.B.; Torres- Valencia, M.K., ChamorroCevallos, G. and Zooiga-Estrada, A. (2008)Spirulina as an antiviral Agent, in M.E. Gershwin \& Amha belay (ed.) Spirulina in human nutrition and health, CRC press, Taylor \& Francis, pp. 227.

Belay,A.(2002). The potential application of Spirulina(Arthrospira) as a nutritional and therapeutic supplement in health management, Journal of the American Nutraceutical Association, 5 (2):, pp. 1-24, Jama, 27.

Belay, A. (2008).Spirulina (Arthrospira) production and quality assurance in M.E. Gershwin and Amha Belay (ed.) Spirulina in human nutrition and health, CRC press, Taylor \& Francis, pp. 16-40.

Ciferri,O.(1983).Spirulina, the edible microorganism, Microbiological reviews, American Society for Microbiology. 47 (4): pp. 551-578.

Diraman, H.; Koru, E. and Dibekliolgu, H. (2009).Fatty acid profile of Spirulina platensis used as a food supplement. The Israli Journal of Aquaculture- Bamideh 61(2): pp. 134-142.

Duncan,H.B.(1955).Multiple range and multiple F.test-Biometrics,It:-42.1.

Dubois, M.; F. Smith; K. A. Gilles; J. Hamilton and P.A. Rebers (1966). Colorimetric method for determination of sugars and related substances Annal. Chem., 28(3): 350-356.

El Hadrami, A. and J. M. AlKhayri.(2012).Socioeconomic and traditional importance of date palm. Emir. J. Food Agric. 24:371-385.

FAO.(2007): Agro-Statistics Database. Database http://faostat.fao.org/site/339/default.aspx

Henrikson, R. (2010)Spirulina World food, How this micro algae can transform your health and our planet, published by Ronore Enterprises, Inc. Po. Box gog. Hana, Maui, Hawaii 967i8 USA, ISBN 1453766987, pp. 195.

Hussien,M.A.(2017).Productive performance of sewy date palms in relation to spraying spirulina platensis algae, plant compost tea, salicylic acid and ocopherol. New York Science Journal 2017;10(7)

Kassem, H. A.; El-Sabrout, M. B.; Attia, M. M.(1997): Effect of nitrogen and potassium fertilization on yield, fruit quality and leaf mineral content in some Egyptian soft date varieties. Alexandria Journal of Agricultural Research; 1997. 42(1):137-157. 32 ref.

Koru, E. (2009).Spirulina micro algae production and breeding in commercial. Turkey Journal of Agriculture, May June 2008, Issue: 11, year 3, pp.133- 134.

Masoud,A.A.(2017).Effect of plant compost enriched with spirulina platensis algae as a partial replacement of mineral $\mathrm{N}$ fertilizers on early sweet grapevine. J. Plant Production, Mansoura Univ., Vol. 8(11): 1247 - 1252, 2017

Mohamed, H.M.S. (2017).Effect of vine load and spraying citric acid on fruiting of Superior grapevines. M.Sc. Thesis Fac. of Agric. Minia Univ. Egypt.

Montasser, A. S.; El-Hammady, A. M.; Khalifa, A. S.(1993): Effect of potash fertilization on "Seewy" date palms. I. Effect on growth and mineral content of leaves.Egyptian Journal of Horticulture; 1991, publ. 1993. 18(2):211-220. 11 ref.

Mostafa, F. M. A. (2006). Physiological effects of yeast and effective microorganisms (EM1) application on Zaghloul date palm. Assiut Journal of Agricultural Sciences; 2006. 37(2):69-82. 16 ref.

Primavesi A. M. (1999). Determination of plant health by their magnetic emanation and its improvement with EM. $5^{\text {th }}$ Inter. Conf. on Kyusei nature Farming, Bangkok, Thailand, 23-26 Oct., 219-225.

Peach, K and Tracey, I.M.V. (1968): Modern Methods of Plant Analysis, Vol. 11 p. 37-38.

Russo, A. and Berlyn, G.P. (1990). The use of organic biostimulants to help low input sustainable agriculture. J. Sus. Agric., 1(2):9-42.

Saric, M. R. K.; R. Curie; T.C. Cupina and I. Geric (1967):-Univerzit et unovon sodu. Ptaktikum Iz Frziologize Biljaka- Beograd, Haucua Anhia pp. 215. 
SAS Institute (1994). SAS/STAT User's Guides Statistics. Vers. 6.04, $4^{\text {th }}$ Ed., SAS Institute Inc., Cary, N.C., USA.

Snedecor, G. W. and Cochran, G. W. (1967): Statistical Methods (sixth ed.). Iowa State University Press.U.S.A pp 20-25.

Summer. M. E. (1985).Diagnosis and Recommendation. Integrated System (DRIS) as a guide to Orchard fertilization. Hort. Abst. 55 (8). 7502 .

Wilde, S. A.; Corey, R. B.; Layer, J. G. and Voigt, G. K. (1985).Soils and Plant Analysis for Tree Culture. Mohan Primlani, Oxford \& IBH Publishing Co., New Delhi, India, p 1- 142.

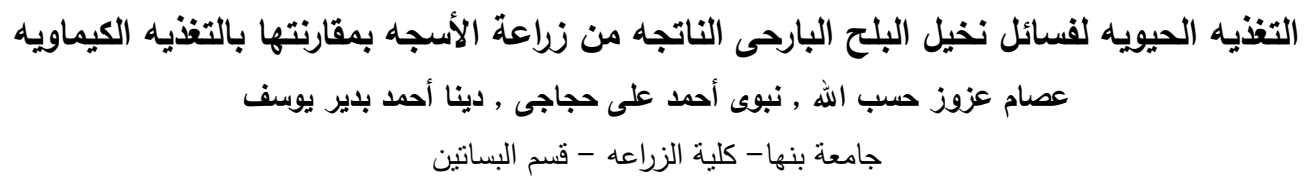

نم استخدام انواع مختلفه من التغذيه الحيويه مثل مستخلص الطحالب اسبيرولينا بتركيز 20 مل لتز ماء رشاعلى الأوراق و 40 مل لتر ماء فى حالة الاضافه الأرضيه وكذا المنشط الحيوى Em1 بتركيز 25 مل لتز ماء رشا على الأوراق و 50 مل لتز ماء للاضافه الأرضيه

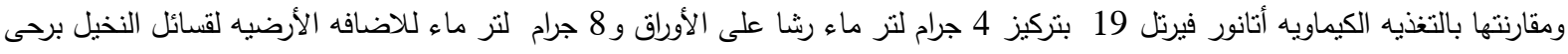

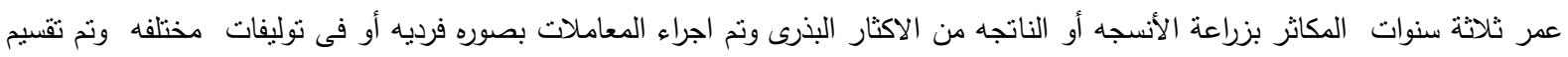

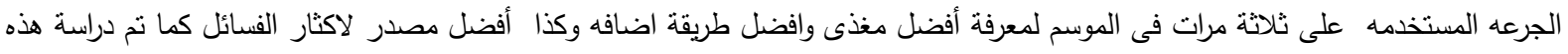
المعاملات على الكلوروفيل (أ ب ) وبيتا كاروتين والكربوهيدرات الكليه والنسبه المئويه لكل من النبتروجين والفوسفور والبوتاسيوم والماغنسيوم والحديد

وتوصلت النتائج الى ظهور تفوق للمنشط الحيوى فى ذيادة معظم قياسات النمو المختلفه (عدد الأوراق - طول الساق - سمك الساق) وأدى

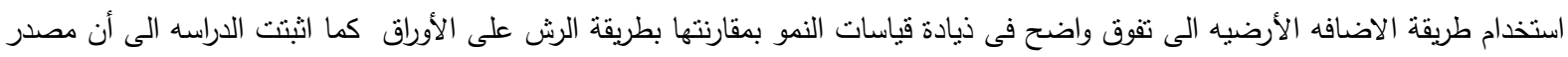

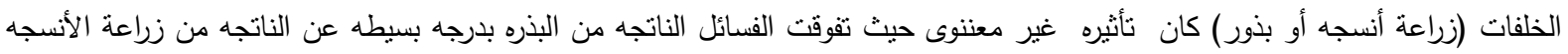

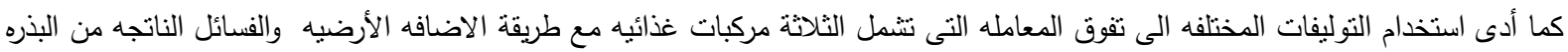

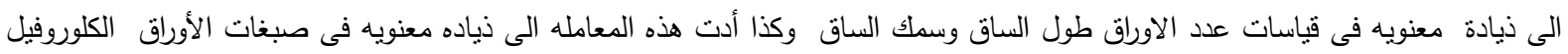

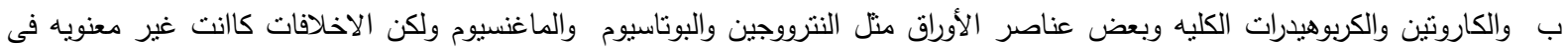
حالة الفوسفور والحديد. 